\title{
Genetic evaluation models for resistance to ticks in a crossbred Angus-Nellore population
}

\author{
André Padilha Bravo ${ }^{*}$ (D) Alan Miranda Prestes $^{2}$ (D) Mauricio Morgado de Oliveira ${ }^{1}$ (D) \\ Vanerlei Mozaquatro Roso ${ }^{3}$ (D) Fernanda Cristina Breda Mello ${ }^{1}$ (D) Paulo Roberto Nogara Rorato ${ }^{1}$ (D)
}

${ }^{1}$ Departamento de Zootecnia, Universidade Federal de Santa Maria (UFSM), 97105-900, Santa Maria, RS, Brasil. E-mail: andrepadilhazootecnia@gmail.com. *Corresponding author.

${ }^{2}$ Programa de Pós-graduação em Sanidade e Produção Animal, Universidade do Oeste de Santa Catarina (UNOESC), Xanxerê, SC, Brasil. ${ }^{3}$ GenSys Consultores Associados S/S Ltda, Porto Alegre, RS, Brasil.

\begin{abstract}
This research identified the animal model that best describes the genetic and residual variations for tick counts in yearlings from a crossbred Angus-Nellore population of 6,951 animals that are progenies of 382 bulls and 6,198 cows. Genetic values were predicted by the Bayesian inference methodology. The models tested were: Traditional Animal, and Crossbred Animal with and without segregation, considering residual homoscedastic and heteroscedastic variances. The criteria of choice were the number of parameters, deviance information, and predictive order, which indicated the best fitfor the Traditional Animal model and Crossbred Animal model (with segregation), both with residual heteroscedastic Gaussian variance. The mean values of fixed genetic effects were positive and similar in the both models, indicating that animals with higher proportion of the Angus breed had greater infestation, and the Nellore breed was an important addition for resistance to ticks. The estimated genetic variation by the heteroscedastic Gaussian Animal model for the Nellore breed was 4.54-fold higher than that estimated for the Angus breed. The estimates of heritability of the different genetic groups ranged from 0.12 to 0.15 and from 0.01 to 0.35 , respectively, for the Traditional Animal model and for the heteroscedastic Gaussian crossbred model. The Spearman's rank-order correlation for the predicted genetic values was 0.94, considering all sires. However, when considering the top 10\%, 20\%, and 30\% sires, differences in ranking were more evident (0.28 to 0.67). The Crossbred Animal model with segregation and heterogeneous residual variances was the most appropriate for genetic evaluation of tick counts on animals from Angus-Nellore crossings.
\end{abstract}

Key words: heteroscedasticity of variances, crossbred animal model, Spearman's correlation.

Modelos de avaliação genética para resistência a carrapatos em uma população mestiça de Angus-Nelore

RESUMO: O objetivo neste trabalho foi identificar o modelo animal que melhor descreve a variação genética e residual para a característica contagem de carrapatos ao sobreano, em uma população multirracial Angus-Nelore constituida por 6.951 animais, filhos de 382 touros e 6.198 vacas. Os valores genéticos foram preditos a partir da metodologia de inferência Bayesiana utilizando os seguintes modelos: Animal Tradicional, Animal Multirracial sem e com segregação, considerando as variâncias residuais homo ou heterocedástica. Os critérios de escolha foram o Número de Parâmetros, a Informação de Deviance e a Ordenada Preditiva, os quais apontaram os Modelos Animal Tradicional e o Multirracial com Segregação, ambos com variância residual Gaussiana heterocedástica, como os de melhor ajuste. Os valores médios dos efeitos genéticos fixos foram positivos e similares nos dois modelos, sugerindo que os animais com maior proporção da raça Angus sofreram maior infestação e atribuindo-se, portanto, a raça Nelore importante papel na resistência ao carrapato. Verificou-se que a variância genética estimada pelo Modelo Animal Gaussiano heterocedástico para a raça Nelore foi 4,54 vezes maior do que a estimada para a raça Angus. As estimativas de herdabilidade nos diferentes grupos genéticos variaram de 0,12 a 0,15 e de 0,01 a 0,35, respectivamente, no Modelo Animal Tradicional e no Multirracial Gaussiano heterocedástico. A correlação de ordenamento de Spearman entre os valores genéticos preditos, considerando todos os reprodutores da população, foi 0,94. Contudo, ao considerar os melhores touros, TOP $10 \%$, 20\% e $30 \%$, as diferenças com relação ao ordenamento foram mais evidentes (0,28 a 0,67). O modelo Animal Multirracial com Segregação com variâncias residuais heterogêneas foi o mais apropriado para avaliação genética da característica Contagem de Carrapatos de animais produtos do cruzamento Angus-Nelore.

Palavras-chave: correlação de Spearman, heterocedasticidade, modelo animal multirracial.

\section{INTRODUCTION}

Rhipicephalus (Boophilus) microplus is an ectoparasite that attacks bovine animals, hinders significantly their performance by causing stress, interferes on weight gain, favors the occurrence of myiasis, depreciates the skin quality, and transmits protozoans that cause diseases such as anaplasmosis and babesiosis. 
The economic losses to the Brazilian livestock caused by ticks in bovine animals reach U\$ 968 million (GRISI et al., 2014). In addition, the consumer market demands bovine meat free from chemical residues, which can have negative impacts on the environment and human health (MOTA et al., 2016). The use of acaricides to control tick infestations is the most common management adopted by producers. However, this is seldom done strategically and with a technical follow up, generating consequences by incorrect use that increase the parasite resistance to commercial molecules. Moreover, the incorrect disposal of bottles, and residues of antibiotics in meat products are undesirable.

An alternative to the use of chemical products is the use of genetically resistant animals to tick infestation, which minimizes losses and; consequently, increases the productivity of the system. Previous studies estimated heritability values between 0.15 and 0.44 (BUDELI et al., 2009; MOTA et al., 2016; PRAYAGA et al., 2009), denoting the potential for slow genetic progress for this trait in purebred and crossbred animals. However, an advantage for production systems is an efficient selection of more resistant animals requires an accurate genetic evaluation, since mistakes in animal selection can result in losses in the short and long terms.

Several studies based on gene expression for the immune responses to the tick have been conducted (STEAR \& WAKELIN, 1998; STEAR et al., 1990; OLIVEIRA et al., 2013). However, recent studies of broad genomic association (CARDOSO et al., 2015; MOTA et al., 2016; MAPHOLI et al., 2016) have not identified many regions with great effect on tick resistance. This indicates that there are no quantitative trait loci responsible for a significant proportion of the genetic variation for traits (MACLEOD et al., 2016).

Crosses between taurus and zebu breeds are increasing in the last years because of the benefits of heterosis and complementarity, with the objective of combining resistance and adaptability traits of zebu breeds with productive and quality traits of taurus breeds. However, most genetic evaluation of crossbred populations disregards the effects of the crossing and its gene interactions.

An accurate evaluation of crossbred sires requires adequacy of models commonly used in genetic evaluation of purebred animals, since not only the additive but also the non-additive genetic merit, within and between breeds, contribute to the total genetic merit of an animal (MILLER, 2010). CARDOSO
\& TEMPELMAN (2004) evaluated a crossbred population and proposed a Crossbred Animal model that includes fixed additive and non-additive genetic effects with individual random deviances, based on LO et al. (1993), as a satisfactory, parsimonious alternative for genetic evaluation of mixed populations.

Moreover, MOTA et al. (2016). reported that most current genetic evaluation methodologies assume homogeneous residual variances between environments; although, residual heteroscedasticity evidences had been reported between contemporary groups for milk production (TORRES et al., 2000) and post-weaning weight gain (CARDOSO \& TEMPELMAN, 2012; CARVALHEIRO et al., 2002).

The objective of this research was to identify the animal model that better describes genetic and residual variations, to evaluate the genetic variability, and rank the best sires according to the genetic evaluation for tick counts in yearlings from a crossbred Angus-Nellore population.

\section{MATERIALS AND METHODS}

The database used was provided by private companies - Gensys Associate Consultants S/C Ltd and Natura South American Genetics. The records consisted of ticks counts in 6,951 animals of different crosses between the Angus and Nellore breeds and with mean age of 554 days; they were progenies of 382 sires and 6,198 cows and bred in 31 farms in different states of the Midwest, Southeast and South regions of Brazil (between latitudes - 11.2 and - 29.8) from 2002 to 2016 (Table 1). The consistency of information in the database was evaluated through the $R^{\circledR}$ Core Team program (TEAM, 2013).

Tick count (TC) was made according to the methodology described by WHARTON \& UTECH (1970) and transformed for normalization by: $T C t=$ $\log 10(T C+1, .001)$. The data were edited forming contemporary groups (CG), grouping animals born in the same year and season, having the same sex, subjected to similar feed management, and bred in the same farm; each group were formed by at least four animals. Subsequently, the connection between contemporary groups was tested based on the total number of genetic ties, using the AMC program (ROSO \& SCHENKEL, 2006); data from sires with less than four descendants and data from animals with three standard deviation above or below the mean for ticks counts within the $\mathrm{CG}$ were excluded. After data restriction, 255 groups of contemporaries remained.

The Crossbred Animal model used was based on the Bayesian hierarchical model proposed 
Table 1 - Description of the data set for tick count for a crossbred Nellore (N)-Angus (A) population.

\begin{tabular}{|c|c|c|c|c|c|c|c|}
\hline \multirow[t]{2}{*}{ Description } & \multicolumn{6}{|c|}{ - } & \multirow[t]{2}{*}{ Total } \\
\hline & $100 \%$ Angus & $3 / 4 \mathrm{~A}$ & $5 / 8 \mathrm{~A}$ & $9 / 16 \mathrm{~A}$ & $1 / 2 \mathrm{~A}$ & $1 / 4 \mathrm{~A}$ & \\
\hline No. of animals with record & 1.606 & 678 & 3.465 & 1.006 & 196 & 0 & 6.951 \\
\hline $\begin{array}{l}\text { Phenotypic mean ( } \pm \text { standard } \\
\text { deviation) }\end{array}$ & $\begin{array}{c}2.3 \\
(2.7)\end{array}$ & $\begin{array}{c}6.9 \\
(14.1)\end{array}$ & $\begin{array}{c}3.5 \\
(8.9)\end{array}$ & $\begin{array}{c}13.8 \\
(27.5)\end{array}$ & $\begin{array}{c}20.1 \\
(31.9)\end{array}$ & $\begin{array}{c}7.6 \\
(12.2)\end{array}$ & $\begin{array}{c}5.8 \\
(15.3)\end{array}$ \\
\hline $\begin{array}{l}\text { Number of sires with progeny } \\
\text { Record }\end{array}$ & 153 & 15 & 203 & 9 & 2 & 0 & 282 \\
\hline $\begin{array}{l}\text { Number of dams with progeny } \\
\text { Record }\end{array}$ & 1.505 & 347 & 1.858 & 727 & 1.394 & 367 & 6.198 \\
\hline No. of animals in the pedigree & 3.143 & 1.030 & 5.474 & 1.733 & 1.588 & 367 & 13.335 \\
\hline
\end{tabular}

by CARDOSO \& TEMPELMAN (2004), which considers specific genetic variations for each breed and genetic variation due to segregation between breeds, corresponding to the additional variance reported in the $F_{2}$ generation in relation to $F_{1}(L O$ et al., 1993):

$Y_{i j k}=\mu+C G_{i}+\beta_{A C}\left(A C_{j}\right)+\beta_{A C 2}\left(A C_{j}^{2}\right)+$ $\beta_{A}\left(f_{k}\right)+\beta_{D}\left(\delta_{k}\right)+\beta_{A A I}\left(2\left[1-f_{k}\right] f_{k}\right)+u_{k}+e_{i j k}$

where $Y_{i j k}$ is the record of TCt in the $\mathrm{k}^{\text {th }}$ animal of the $\mathrm{i}^{\text {th }} \mathrm{CG}$; $\mu$ is the constant; $g c i$ is the effect of the $i^{- \text {th }} \mathrm{CG}$

$(i=1,2, \ldots, 255)$, with $c g i \sim N\left(0, \sigma_{c g}^{2}\right)$ for all $i ; \beta^{\prime} s$ are the coefficients of regression associated with age at count (AC) in days ( $365 \leq \mathrm{AC} \leq 729)$, fixed additive effect of the Angus breed $(A)$, dominance effect of the Nellore-Angus breed $(D)$, and epistatic additive $\times$ additive effect of Nellore-Angus crossbred $(A A I)$. The coefficient $f_{k}$ represent the expected proportion of genes of the Angus breed in the animal $k$; and $\delta_{k}$ is the coefficient of heterozygosity

$\left(\delta_{k}=f_{k_{A}^{P}} f_{k_{N}^{A}}+f_{k_{N}^{P}} f_{k_{A}^{M}}\right)$ obtained through the father (P) and mother (M) generations by means of the probability that one of the alleles is from the Nellore breed $\left(f_{k N}\right)$ and the other is from the Angus breed $\left(f_{k}\right.$ ${ }_{A}$ ) for a randomly chosen locus from a $k$ individual. Moreover, $2\left[1-f_{k}\right] f_{k}$ is the epistatic coefficient additive $\times$ additive for the animal $k$ based on the information of loss by recombination of KINGHORN(1993); $\mu_{k}$ is the additive genetic effect of the animal $k$, assuming that $u=\left\{u_{k}\right\}\left\{u_{k}\right\}_{k=1}^{13.335} \sim N(0, G)$, in which $G$ is the matrix of crossbreed genetic (co)variance, function of specific genetic variation by breed for Angus $\sigma_{g}^{2}$ (1) and Nellore $\sigma_{g(2)}^{2}$, and the variance of segregation between the two breeds $\sigma_{S(12)}^{2}$ and the additive kinship between animals; and $e_{i j k}$ is the residual error with normal homoscedastic distribution $\left(e_{i j k} \sim N\left(0, \sigma_{e}^{2}\right)\right)$ for all combinations $i, j$, and $k$.

Three models were tested: 1) Traditional Animal model (TAM), in which the genetic variation was considered homogeneous between breeds $\left(\sigma_{g(1)}^{2}=\right.$ $\left.\sigma_{g(2)}^{2}\right)$, the segregation variance was considered equal to zero $\left(\sigma_{S(12)}^{2}=0\right)$, and the population was considered one breed; 2) Crossbred Animal model without segregation (CAM-S), considering the differences of genetic variation between breeds $\left(\sigma_{g(1)}^{2} \neq \sigma_{g(2)}^{2}\right)$ and segregation variance equal to zero $\left(\sigma_{S(12)}^{2}=0\right) ; 3$ ) Crossbred Animal model with segregation (CAM+S), considering the differences of genetic variation between breeds $\left(\sigma_{g(1)}^{2} \neq \sigma_{g(2)}^{2}\right)$ and the existence of segregation between them $\left(\sigma_{S(12)}^{2} \neq 0\right)$.

Subsequently, four different specifications of distribution of residues were tested in a $2 \times 2$ factorial arrangement; the first factor consisted of the nature of the homoscedastic $(\mathrm{HO})$ and heteroscedastic (HE) variances, and the second factor consisted of the marginal distribution of the Gaussian $(\mathrm{G})$ and Student $t$ (T) residues, according to CARDOSO et al.(2005):

1) $\mathrm{THE}=$ heteroscedastic Student $t$ errors, assuming

$\sigma_{\theta_{i k}}^{2}=\sigma_{e}^{2} \tau_{G C_{i}}\left(\gamma_{A}\right)^{f_{k}}\left(\gamma_{D}\right)^{\delta_{k}} w_{k}^{-1}$ as the specific residual variance of the record of the animal $k$, determined by a multiplying function of a global variance $\left(\sigma^{2}\right)$ and scalar factors for CG $\left(\tau_{G C i}\right)$; proportion of the Angus breed $\left(\gamma_{A}\right)$; heterozygosity $\left(\gamma_{D}\right)$; and a weighted variable for the record of animal $k\left(\mathrm{w}_{\mathrm{k}}\right)$, whose conditional 
distribution is defined as $w_{k} \sim \operatorname{Gamma}\left(\frac{v_{\epsilon}}{2}, \frac{v_{\epsilon}}{2}\right)$ for all $k$, with $w_{k}>0$, in which $v>0$ represents the degrees of freedom. The CG distribution over the residual variance $\left(\tau_{G C}\right)$ was considered a random variable with a priori distribution $\tau_{G C_{i}} \sim \operatorname{Gamma}^{-1}(\eta, \eta-1)$ for all $k, E\left(\tau_{G C_{i}}\right)=1$ and $\operatorname{Var}\left(\tau_{G C_{i}}\right)=\frac{1}{n-2}$, with $\eta>1$ as the heteroscedasticity parameter;

2) $\mathrm{THO}=$ homoscedastic Student $t$ errors, assuming $\tau_{G C_{i}}=\left(\gamma_{A}\right)^{f_{k}}=\left(\gamma_{D}\right)^{\delta_{k}}=1$ and, thus, a homoscedastic residual variance for the record of the animal $k$, given by $\sigma_{e}^{2} w_{k}^{-1}$;

3) $\mathrm{GHE}=$ heteroscedasticerrors with marginal distribution of Gaussian residues, assuming $w_{k}=1$ for all $k$, as follows: $\sigma_{e_{i k}}^{2}=\sigma_{e}^{2} \tau_{G C_{i}}\left(\gamma_{A}\right)^{f_{k}}\left(\gamma_{D}\right)^{\delta_{k}}(1)^{-1}$;

4) $\mathrm{GHO}=$ homoscedastic Gaussian errors, assuming $\tau_{G C_{i}}=\left(\gamma_{A}\right)^{f_{k}}=\left(\gamma_{D}\right)^{\delta_{k}}=1$ and $w_{k}=1$, thus, $\sigma_{e_{i k}}^{2}=\sigma_{\theta}^{2}$.

The additive genetic variance of a breed group $g\left(\sigma_{g}^{2}\right)$ formed by two breeds ( $\mathrm{r}=1$ and 2$)$ was obtained by the following formula(LO et al., 1993): $\sigma_{g}^{2}=f_{1}^{g} \sigma_{g(1)}^{2}+f_{2}^{g} \sigma_{g(2)}^{2}+2\left(f_{1}^{p} f_{2}^{p}+f_{1}^{m} f_{2}^{m}\right) \sigma_{s(12)}^{2}$, where $f_{r}^{i}$ is the fraction of the breed $r$ observed in the breed group $(i=g)$ and in paternal $(i=p)$ and maternal $(i=m)$ groups. Consequently, the heritability of this group is obtained by:

$h_{g}^{2}=\frac{\sigma_{g}^{2}}{\sigma_{g}^{2}+\sigma_{\theta}^{2}}$

The components of (co)variances were estimated using the Bayesian inference, according to the Monte Carlo method via Markov chain (MCMC), with 110,000 iterations, saving samples at each 10 cycles after the 10,000 initial cycles. The genetic analysis was done using the Intergen 1.3 program (CARDOSO et al., 2016). The Markov Chain convergence was verified using the criteria of HEIDELBERGER \& WELCH (1983) and GEWEKE (1991) through the Bayesian Output Analysis (BOA) package of the R 3.3.1 program (SMITH, 2007).

The choice of the best model was done using statistical criteria of number of parameters $(\mathrm{Np})$, deviance information (DIC) (SPIEGELHALTER et al., 2002), and conditional predictive ordinate (CPO) (GELFAND, 1996).Additionally, the Spearman's correlations between genetic values were estimated for the most adequate models for the tick counts in the top 10, 20, and 30sires.

\section{RESULTS AND DISCUSSION}

The models using Student terrors did not converge. Those that best fitted to the dataset were $\mathrm{TAM}(\mathrm{GHE})$ and $\mathrm{CAM}+\mathrm{S}(\mathrm{GHE})$, with more adequate heteroscedasticity in $77.77 \%$ of the comparisons, according to the statistical criteria presented in table 2 .
When testing crossbred models involving the Angus and Nellore breeds, some studies reported superiority of the model without segregation for post-weaning weight gain (OLIVEIRA et al., 2010; PRESTES et al., 2019). However, BIRCHMEIER et al. (2002) evaluated Angus-Hereford and NelloreHereford populations and found that $11.4 \%$ to $16 \%$ of the total additive variance for weight at birth was explained by the variance of segregation in F2; they reported that genetic evaluations using the covariance crossbred theory require the estimate of the variance of segregation.

WINKELMAN \& SCHAEFFER (1988) reported that the effect of the heterogeneity of variances is important for the selection of cows, young sires, and calves because these animals have records within a single herd/environment and, thus, their evaluations can be affected by differences in environmental variances. The effects of sex, farm, and animal age, for example, can be classified as sources of heteroscedasticity; in the case of crossbred populations, the composition of the breed and its genetic interactions can also be considered causes of heteroscedasticity (CARDOSO et al., 2005; OLIVEIRA et al., 2001; RODRÍGUEZ-ALMEIDA et al., 1995).

The mean values of fixed genetic effects for tick count were positive and similar in TAM(GHE) and $\mathrm{CAM}+\mathrm{S}(\mathrm{GHE})$ (Table 3$)$. The highest value was reported for the additive effect (1.24), followed by the epistatic effect $(\cong 0.95)$ and dominance effect

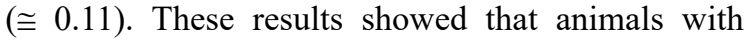
higher proportion of the breed presented higher tick infestation, indicating that the contribution of the Nellore breed to the crossing is important for resistance to this parasite. However, similar results for productive traits of crossbred populations are not reported in the literature (BERTOLI et al., 2015; CARDOSO \&TEMPELMAN, 2004; LOPES et al., 2010; OLIVEIRA et al., 2010), which report losses only for the epistatic effect.

The residual variance obtained by $\mathrm{CAM}+\mathrm{S}(\mathrm{GHE})$ was $46 \%$ lower than that of TAM(GHE) (Table 4). TAM(GHE) estimated only the genetic variance, common for both breeds; whereas $\mathrm{CAM}+\mathrm{S}(\mathrm{GHE})$ estimated the genetic variance of the breeds individually and the variance of segregation between them. The genetic variance estimated by TAM(GHE) was similar to that estimated for the Angus breed by $\mathrm{CAM}+\mathrm{S}(\mathrm{GHE})$; this can be related to the higher frequency of genes of the Angus breed in the population (69.34\%). According to CARDOSO et al. (2004), the crossbred model can adequately describe the genetic variability of different breed groups in 
Table 2 - Means of deviance, penalization by number of parameters (pD), deviance information criterion $(\mathrm{DIC}=\mathrm{deviance}+\mathrm{pD})$, and conditional predictive ordinate deviance (CPODEV) for the Traditional Animal model (TAM), and the Crossbred Animal model without segregation (CAM-S) and with segregation (CAM+S), with Gaussian Homoscedastic (GHO) and Heteroscedastic (GHE) errors.

\begin{tabular}{lcccc}
\hline Model & Deviance & $\mathrm{pD}$ & DIC & CPODEV \\
\hline TAM(GHO) & 3714.85 & 2033.07 & 5747.92 & 6707.74 \\
TAM(GHE) & 3598.75 & 1980.20 & 5578.95 & 6645.69 \\
CAM-S(GHO) & 2607.87 & 2504.77 & 5112.64 & 6620.88 \\
CAM-S(GHE) & 2851.64 & 2111.79 & 4963.43 & 6582.99 \\
CAM+S(GHO) & 994.5 & 3272.15 & 4266.65 & 6542.94 \\
CAM+S(GHE) & -1305.48 & 3284.38 & 1978.90 & 6094.28 \\
\hline
\end{tabular}

crossbred populations. Therefore, not considering the effects of the two breeds and segregation generates an incorrect decomposition of genetic variance and an overestimation of the residual variance.

The variance genetic estimated by $\mathrm{CAM}+\mathrm{S}(\mathrm{GHE})$ for the Nellore breed was 4.54 fold higher than that estimated for the Angus breed, which resulted in higher heritability estimates for genetics groups with participation of the Nellore breed (Table 4 and Figure 1). This can make the selection process for genetically superior animals easier and more efficient. The estimates of heritability by TAM(GHE) varied from 0.12 (5/8Angus) to 0.15 (9/16 Angus); and those estimated by $\mathrm{CAM}+\mathrm{S}(\mathrm{GHE})$ varied from 0.01 (Angus) to 0.35 (5/8 Angus), showing that the inclusion of this trait as a criterion of selection in breeding programs can generate genetic progress in short to medium terms, mainly for populations with higher contribution of the Nellore breed. CARDOSO et al. (2006) evaluated Braford bovine and reported heritability of 0.34 ; and BIEGELMEYER et al.(2012)found that the selection of tick-resistant bovine cattle as a strategy of control is used with

Table 3 - Means and standard deviations (a posteriori) of fixed genetic effects for tickcount.

\begin{tabular}{lcc}
\hline $\begin{array}{l}\text { Effect } \\
\text { (Parameters) }\end{array}$ & TAM(GHE) & CAM+S(GHE) \\
\hline Additive & $1.24 \pm 0.29$ & $1.24 \pm 0.35$ \\
Dominance & $0.11 \pm 0.06$ & $0.12 \pm 0.06$ \\
Epistasis & $0.95 \pm 0.40$ & $0.97 \pm 0.46$ \\
\hline
\end{tabular}

$\mathrm{TAM}(\mathrm{GHE})=$ Traditional Animal model, and CAM $+\mathrm{S}(\mathrm{GHE})$

= Crossbred Animal model with segregation, both with

Gaussian Heteroscedastic errors good efficiency in Australia, which has similar climate conditions to those in Brazil. UTECH \& WHARTON (1982) evaluated an Australian Illawara Shorton herd after 15 years of selection and found that the number of animals with phenotypes of high resistance increased from $89.2 \%$ to $99 \%$, without negative effects on milk production.

The Spearman's rank-order correlation between the genetics values predicted by the $\mathrm{TAM}(\mathrm{GHE})$ and $\mathrm{CAM}+\mathrm{S}(\mathrm{GHE})$ models, considering all sires in the population, was 0.94. Similar results were reported by PRESTES et al.(2019) and OLIVEIRA et al. (2010) for post-weaning weight gain in Angus/Nellore populations.

Considering the top $10 \%, 20 \%$, and $30 \%$ sires, the differences were more evident, especially for the top $20 \%$ and $30 \%$ sires (Figure 2), which presented Spearman's rank-order correlations of 0.28 and 0.51 , respectively. Top $10 \%$ sires had rank-order correlation of 0.67 , however, it is low considering the importance of a correct selection of genetically superior animals. In addition, the rank-order of sires in a genetic evaluation is one of the factors that influence the price of sire and its semen, i.e., the use of an inappropriate model generates mistakes in genetic evaluation that result in economic losses to the breeder.

The highest rank-order correlation reported (top $10 \%$ sires) can be attributed to the lower genetic variability of this population, which is in the top of the pyramid (herd nucleus). The lowest rank-order correlations reported (top 20\% and $30 \%$ sires) can be explained by the lower selection pression on these animals. According to PRESTES et al. (2019), the lower the selection intensity, the higher the genetic variability. The genetics values predicted by the TAM(GHE) model were higher than those predicted by the $\mathrm{CAM}+\mathrm{S}(\mathrm{GHE})$, probably because the TAM(GHE) model does not consider 
Table 4 - Variances estimated by the Traditional Animal model (TAM) and by the Crossbred Animal model with segregation (CAM+S), both with Gaussian Heteroscedastic Errors (GHE), for the resistance to ticks in a crossbred Angus-Nellore population.

\begin{tabular}{|c|c|c|c|}
\hline Variance & Mean $\pm \mathrm{SE}$ & Mode & $\mathrm{RC}(95 \%)$ \\
\hline Genetic & $0.032 \pm 0.004$ & 0.030 & $0.025-0.040$ \\
\hline Residual & $0.344 \pm 0.069$ & 0.391 & $0.23-0.50$ \\
\hline \multicolumn{4}{|c|}{ - } \\
\hline Angus & $0.035 \pm 0.004$ & 0.033 & $0.028-0.045$ \\
\hline Nellore & $0.159 \pm 0.018$ & 0.156 & $0.130-0.200$ \\
\hline Segregation & $0.025 \pm 0.005$ & 0.022 & $0.018-0.035$ \\
\hline Residual & $0.184 \pm 0.058$ & 0.198 & $0.099-0.330$ \\
\hline
\end{tabular}

$\mathrm{RC}=$ Region of credibility (95\%).

variances of breeds separately, as well as variance of segregation (Figure 2).

\section{CONCLUSION}

The use of an inadequate model for genetic evaluation results in errors in the decomposition of variances and mistakes in the rank-order of sires; and the Crossbred Animal model with segregation and heterogeneous residual variances is the most appropriate for genetic evaluation of tick count in animals from Angus-Nellore crosses.

In adverse environments for the rearing of animals of the Angus breed, their crossing with

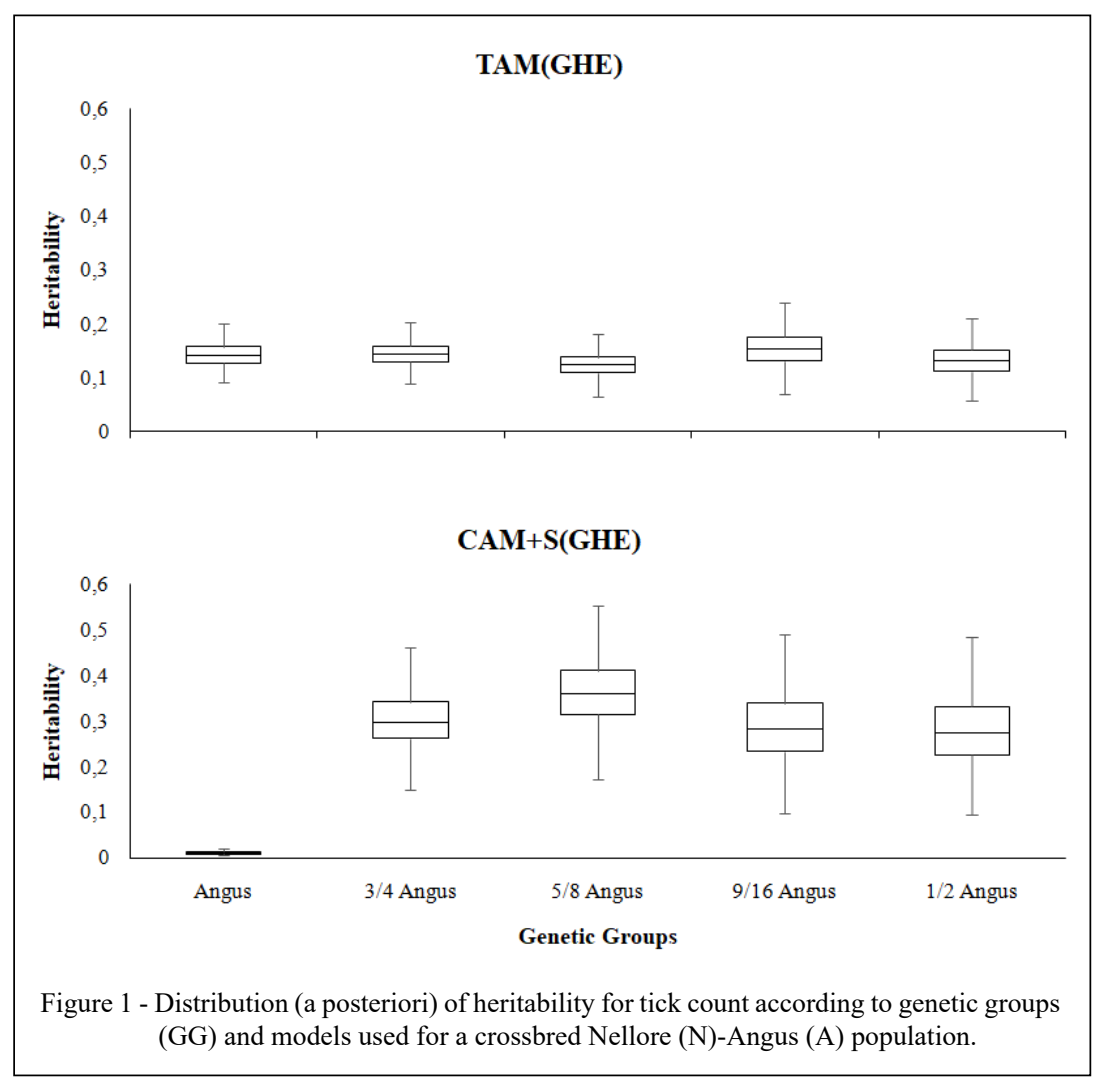

Ciência Rural, v.51, n.10, 2021. 


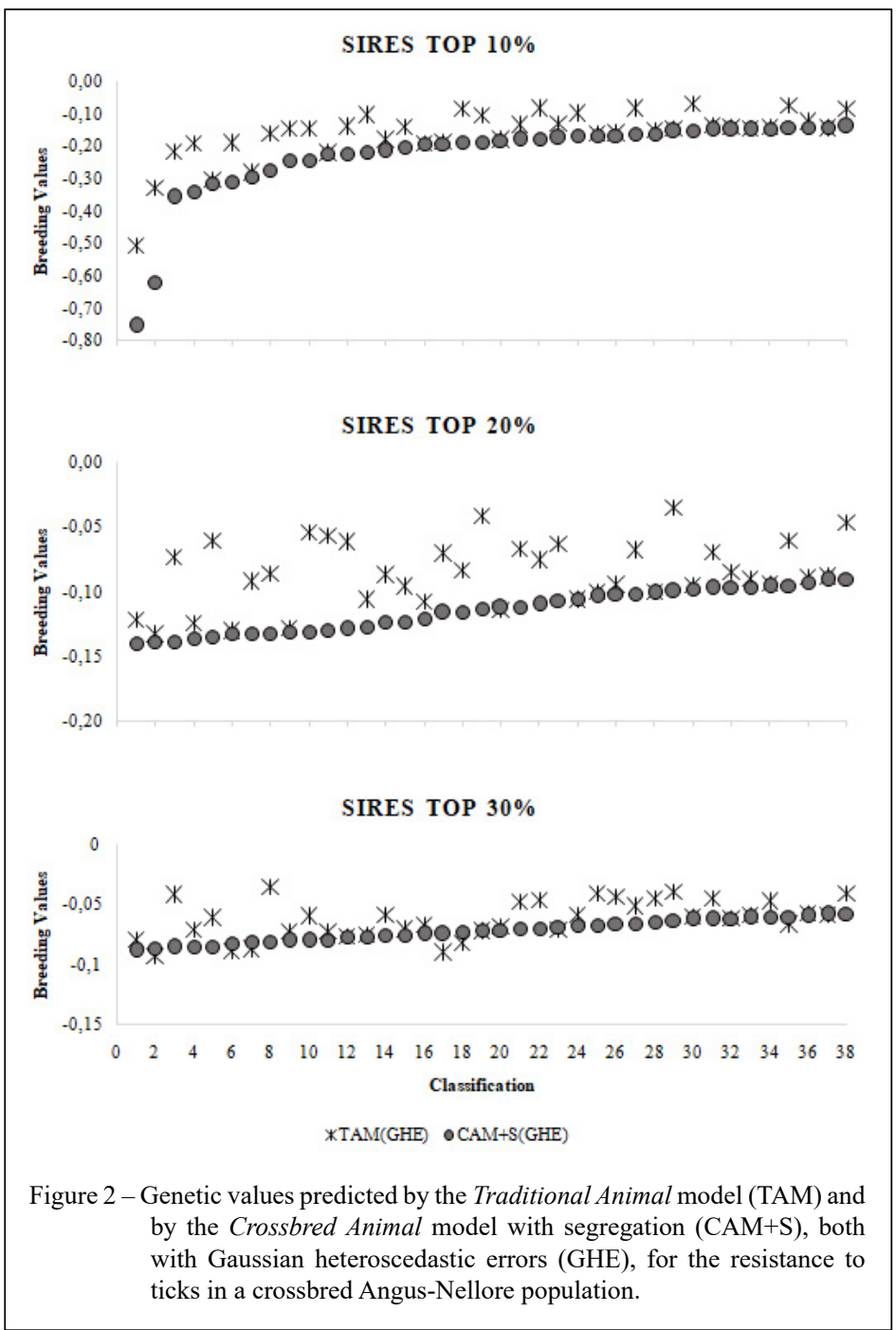

animals of the Nellore breed is an efficient alternative regarding the selection for resistance to ticks.

\section{ACKNOWLEDGMENTS}

The authors thank the Brazilian Conselho Nacional de Desenvolvimento Científico e Tecnológico (CNPq) for granting scholarships.And the financing by the Coordenação de Aperfeiçoamento de Pessoal de Nível Superior (CAPES), Brasil - Finance code 001.

\section{DECLARATION OF CONFLICT OF INTEREST}

The authors declare no conflict of interest. The founding sponsors had no role in the design of the study; in the collection, analyses, or interpretation of data; in the writing of the manuscript, and in the decision to publish the results.

\section{AUTHORS' CONTRIBUTIONS}

The authors contributed equally to the manuscript.

\section{REFERENCES}

BERTOLI, C. D. et al. Modeling breed additive and non-additive genetic effects using a Angus x Nellore crossbred population. Livestock Science, v.176, p.1-13, 2015. Available from: <https:// doi.org/10.1016/j.livsci.2015.03.020>. Accessed: Jan. 17, 2019. doi: 10.1016/j.livsci.2015.03.020.

BIEGELMEYER, P. et al. Bovine resistance to Rhipicephalus (Boophilus) microplus ticks. Archivos de Zootecnia, v.61, n.R, p.1-11, 2012. Available from: <http://www.uco.es/organiza/servicios/publica/az/php/img/web/06_11 33_2295REVISIONResistenciaBiegemeyer.pdf $>$.Accessed: Dec. 18, 2018.

BIRCHMEIER, A. N. et al. Estimation of segregation variance for birth weight in beef cattle. Livestock Production Science, v.76,

Ciência Rural, v.51, n.10, 2021. 
n.1-2, p.27-35, 2002. Available from: <https://doi.org/10.1016/ S0301-6226(02)00013-1>. Accessed: Feb. 15, 2019. doi: 10.1016/ S0301-6226(02)00013-1.

BUDELI, M. A. et al. Genetic parameter estimates for tick resistance in Bonsmara cattle. South African Journal of Animal Science, v.39, n.4, 2009. Available from: $<$ https://doi.org/10.4314/ sajas.v39i4.51125>. Accessed: Dec. 15, 2018. doi: 10.4314 / sajas. v39i4.51125.

CARDOSO, F. F.; TEMPELMAN, R. J. Hierarchical Bayes multiple-breed inference with an application to genetic evaluation of a Nelore-Hereford population. Journal of Animal Science, v.82, n.6, p.1589-1601, 2004. Available from: <https://doi. org/10.2527/2004.8261589x>. Accessed:Jan. 04, 2019. doi: $10.2527 / 2004.8261589 x$.

CARDOSO, F. F.; ROSA, G. J. M.; TEMPELMAN, R. J. Multiple-breed genetic inference using heavy-tailed structural models for heterogeneous residual variances. Journal of Animal Science, v.83, n. 8, p.1766-1779, 2005. Available from: <https://doi.org/10.2527/2005.8381766x>. Accessed: Dec. 02, 2018.. doi: 10.2527/2005.8381766x.

CARDOSO, F. F.; TEMPELMAN, R.J. Linear reaction norm models for genetic merit prediction of Angus cattle under genotype by environment interaction. Journal of Animal Science, v.90, n.7, p.2130-2141, 2012. Available from: <https://doi.org/10.2527/ jas.2011-4333>. Accessed: Feb. 23, 2019. doi: 10.2527/jas.2011-4333.

CARDOSO, F. F. et al. Genomic prediction for tick resistance in Braford and Hereford cattle. Journal of Animal Science, v. 93, p. 2693-2705, 2015. Available from: <https://doi.org/10.2527/jas.20148832>. Accessed: Jan. 04, 2019. doi: 10.2527/jas.2014-8832.

CARDOSO, F. F.; JUNQUEIRA, V.S.; MOTA, R.R. Soluções computacionais para a predição de valores genéticos em animais de produção: manual da versão 1.3 do Programa Intergen. Bagé: Embrapa Pecuária Sul, 2016. 28p. Available from: $<$ http://arquivos.cppsul.embrapa.br/downloads/intergen/Manual do Intergen_1-3_Portugues.pdf $>$.Accessed: Dec. 07, 2018.

CARDOSO, V. et al. Estimates of heritability for resistance to Boophilus microplus tick evaluated by an alternative method in a commercial polled Hereford $\times$ Nelore population in Brazil. p.12-16, 2006. Available from: $<$ https://www.semanticscholar.org/ paper/Estimates-of-heritability-for-resistance-to-tick-by-CardosoFries/fb148d1cbb3b7a513ef0fd8cfac99ac9eae47ea2>. Accessed: Feb. 18, 2019.

CARVALHEIRO, R. et al. Efeitos da heterogeneidade de variância residual entre grupos de contemporâneos na avaliação genética de bovinos de corte. Revista Brasileira de Zootecnia, p. 1680 1688, 2002. Available from: <https://doi.org/10.1590/S151635982002000700010>. Accessed: Dec. 07, 2018. doi: 10.1590/ S1516-35982002000700010.

GELFAND, A. E. Model determination using sampling-based methods. Markov chain Monte Carlo in practice, p.145-161, 1996. Accessed: Feb. 18, 2019.

GEWEKE, J. Evaluating the accuracy of sampling-based approaches to the calculation of posterior moments. Federal Reserve Bank of Minneapolis, Research Department Minneapolis, MN, USA, 1991. V.196. Accessed: Dec. 20, 2018.
GRISI, L. et al. Reassessment of the potential economic impact of cattle parasites in Brazil. Revista Brasileira de Parasitologia Veterinária, v.23, n.2, p.150-156, 2014. Available from: <https:// doi.org/10.1590/S1984-29612014042>. Accessed: Jan. 15, 2019. doi: 10.1590/S1984-2961201404.

HEIDELBERGER, P.; WELCH, P. D. Simulation run length control in the presence of an initial transient. Operations Research, v.31, n.6, p.1109-1144, 1983. Accessed: Dec. 14, 2018.

KINGHORN, B. P. Theory of breed utilization. Design of livestock breeding programs: short course in animal Breeding. Armidale: AGBU, p.187-204, 1993. Accessed: Feb. 14, 2019.

LO, L. L.; FERNANDO, R. L.; GROSSMAN, M. Covariance between relatives in multibreed populations: additive model. Theoretical and Applied Genetics, v.87, n.4, p.423-430, 1993. Available from: <https://doi.org/10.1007/BF00215087>. Accessed: Dec. 04, 2018. doi: 10.1007/BF00215087.

LOPES, J. S. et al. Avaliação do desempenho na pós-desmama para uma população bovina multirracial Aberdeen Angus x Nelore utilizando-se diferentes modelos genéticos. Arquivo Brasileiro de Medicina Veterinária e Zootecnia, v.62, n.6, p.1439 1447, 2010. Available from: <https://doi.org/10.1590/S010209352010000600021>. Accessed: Nov. 05, 2018. doi: 10.1590/ S0102-09352010000600021

MILLER, S. Genetic improvement of beef cattle through opportunities in genomics. Revista Brasileira de Zootecnia, v.39, n. suppl spe, p.247-255, 2010. Available from <http:// www.scielo.br/scielo.php? script $=$ sci $\operatorname{arttext\& pid}=\mathrm{S} 1516-$ $35982010001300027 \& \operatorname{lng}=$ en $\& n r m=i s o>$. Accessed: Feb. 16, 2019. doi: 10.1590/S1516-35982010001300027.

MOTA, R. R et al. Genotype by environment interaction for tick resistance of Hereford and Braford beef cattle using reaction norm models. Genetics Selection Evolution, v.48, n.1, p.3, 2016. Available from: <https://doi.org/10.1186/s12711-015-0178-5>. Accessed: Jan. 07, 2019. doi: 10.1186/s12711-015-0178-5.

OLIVEIRA, C. A. L. de. et al. Heterogeneidade de variâncias nos grupos genéticos formadores da raça Canchim. Revista Brasileira de Zootecnia, v.30, n.4, p.1212-1219, 2001. Available from: $<$ http://www.scielo.br/scielo.php?script=sci arttext\&pid=S151635982001000500012\&lng $=$ en\&nrm $=$ iso $>$. Accessed: Jan. 07, 2019. doi: 10.1590/S1516-35982001000500012.

OLIVEIRA, F. S. et al. Genotipagem de polimorfismos do gene BoLA DRB3. 2 em raças bovinas criadas no Brasil. [S.l.]: In: JORNADA CIENTÍFICA EMBRAPA GADO DE CORTE, 9., 2013, Campo Grande, MS, 2013. Accessed: Jan. 03, 2019

OLIVEIRA, M. M.; CARDOSO, F. F.; OSÓRIO, J. C. da S. Componentes de variância e parâmetros genéticos em uma população multirracial Nelore-Angus sob enfoque Bayesiano. Revista Brasileira de Zootecnia, v.39, n.11, p.2426-2433, 2010. Available from: $<$ http://www.scielo.br/scielo.php?script $=$ sci arttext\&pid $=$ S1516-35982010001100015\&lng $=$ en\&nrm $=$ iso $>$. Accessed: Jan. 04, 2019. doi: 10.1590/S1516-35982010001100015.

PRAYAGA, K. C. et al. Genetics of adaptive traits in heifers and their relationship to growth, pubertal and carcass traits in two tropical beef cattle genotypes. Animal Production Science, v.49, 
n.6, p.413-425. 2009. Available from: <https://doi.org/10.1071/ EA08247>. Accessed: Dec. 12, 2018. doi: 10.1071/EA08247.

PRESTES, A. M. et al. Genetic evaluation models for post-weaning weight gain in a multibreed Angus-Nelore population. Pesquisa Agropecuária Brasileira, 2019. v.54. Available from: <http:// www.scielo.br/scielo.php?script $=$ sci arttext\&pid $=$ S0100-204X20 19000102803\&lng=en\&nrm=iso $>$. Accessed: Feb. 20, 2019. doi: 10.1590/s1678-3921.pab2019.v54.00694.

RODRÍGUEZ-ALMEIDA, F. A. et al. Heterogeneity of variance by sire breed, sex, and dam breed in 200-and 365-day weights of beef cattle from a top cross experiment. Journal of Animal Science, v. 73, n. 9, p. 2579 2588, 1995. Available from: $<$ https://doi.org/10.2527/1995.7392579x $>$. Accessed: Dec. 06, 2018. doi: 10.2527/1995.7392579x.

ROSO, V. M.; SCHENKEL, F S. AMC-A computer program to assess the degree of connectedness among contemporary groups. [S.1.]: Instituto Prociência, 2006. p.13-18.

SMITH, B. J. boa: an R package for MCMC output convergence assessment and posterior inference. Journal of Statistical Software, v.21, n.11, p.1-37, 2007. Available from: <https:// doi.org/10.18637/jss.v021.i11>. Accessed: Jan. 19, 2019. doi: 10.18637 / jss.v021.i11.

SPIEGELHALTER, D. J. et al. Bayesian measures of model complexity and fit. Journal of the Royal Statistical Society: Series B (Statistical Methodology), v.64, n.4, p.583-639, 2002. Available from: $<$ http://doi.wiley.com/10.1111/1467-9868.00353>. Accessed: Nov. 18, 2018. doi:0.1111/1467-9868.00353.

STEAR, M. J.; WAKELIN, D. Genetic resistance to parasitic infection. Revue scientifique et technique-Office international des épizooties, v.17, p.143-149, 1998. Available from: <https:// doi.org/10.20506 / rst.17.1.1089>. Accessed: Jan. 23, 2019. doi: 10.20506 / rst.17.1.1089.

TEAM, R. C. R: A language and environment for statistical computing. 2013.

TORRES, R. de A. et al. Heterogeneity of variance and genetic evaluation of Holstein cattle in Brazil. Revista Brasileira de Zootecnia, v.29, n.4, p.1050-1059, 2000. Available from: $<$ http://www.scielo.br/scielo.php?script=sci arttext\&pid=S151635982000000400015\&lng=en\&nrm=iso $>$. Accessed: Jul. 12, 2019. doi: 10.1590/S1516-35982000000400015.

UTECH, K. B. W.; WHARTON, R. H. Breeding for resistance to Boophilus microplus in Australian illawarra shorthorn and Brahman x Australian illawarra shorthorn cattle. Australian Veterinary Journal, v.58, n.2, p.41-46, 1982. Available from: $<$ https://doi.org/10.1111/j.1751-0813.1982.tb02684.x>. Accessed: Jan. 18, 2019. doi: 10.1111/j.1751-0813.1982.tb02684.x.

WHARTON, R. H.; UTECH, K. B. W. The relation between engorgement and dropping of Boophilus microplus (Canestrini) (Ixodidae) to the assessment of tick numbers on cattle. Australian Journal of Entomology, v.9, n.3, p.171-182, 1970. Available from: $\quad<$ https://doi.org/10.1111/j.1440-6055.1970.tb00788 $\mathrm{x}>$. Accessed: Feb. 11, 2019. doi: 10.1111/j.1440-6055.1970. tb00788.x.

WINKELMAN, A.; SCHAEFFER, L. R. Effect of heterogeneity of variance on dairy sire evaluation. Journal of Dairy Science, v.71, n.11, p.3033-3039, 1988. Available from: <https://doi. org/10.3168/jds.S0022-0302(88)79902-6>. Accessed: Jan. 18, 2019. doi: 10.3168/jds.S0022-0302(88)79902-6. 